\title{
FAMILY-RELATED DETERMINANTS AND IMPLICATIONS OF LOW FEMALE ENROLMENT IN ELECTRICAL TRADE IN ADAMAWA STATE
}

\author{
Zechariah Ishaku' $^{1}$ (iD) Grace James $^{2}$ iD Aniekan Elijah Asukwo ${ }^{2}$ iD \\ ${ }^{1}$ Department of Technical Education, Adamawa State College of Education, Hong, Adamawa State, Nigeria \\ ${ }^{2}$ Department of Electrical Technology Education, Modibbo Adama University, Yola, Adamawa State, Nigeria
}

\section{ARTICLE INFO}

Recieved: 05 August 2021

Revised: 04 October 2021

Accepted: 08 October 2021

\section{Keywords:}

Family-Related Determinants, Family-Related Implications, Low Enrolment, Electrical Installation and Maintenance Works trade

Corresponding Author: Aniekan Elijah Asukwo

Email: aaelija@mautech.edu.ng Copyright (C) 2021, Middle Eastern Journal of Research in Education and Social Sciences.

This work is licensed under the Creative Commons Attribution International License (CC BY 4.0). http://creativecommons.org/licenses/ by $/ 4.0 /$
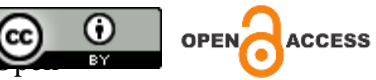

\begin{abstract}
Purpose: This study examined the perceived family-related determinants and implications of the low enrolment of female students in electrical installation and maintenance works in government science technical colleges of Adamawa State. Approach/Methodology/Design: A descriptive survey research design was adopted for the study. The population of the study consisted of 13 Electrical Installation and Maintenance Work Trade (EIMWT) teachers and 129 parents of National Technical Certificate Two (NTCII) EIMWT students (either father or mother) in three Government Science Technical Colleges of Adamawa State. The sample of the study comprised of the entire population, thus no sampling was done. A 20-item questionnaire was developed by the researcher and used for data collection. The questionnaire was validated by three lecturers from the Department of Electrical Technology Education, Modibbo Adama University, Yola, Adamawa State. A reliability coefficient of 0.87 was obtained for the instrument using Cronbach Alpha. Mean was used to answer the research questions while a t-test was used to test the hypotheses.

Findings: The findings of the study revealed low contribution from the female gender to family income in households and increased level of dependency of the female gender on the males in Adamawa State as major perceived family-related implications.

Practical Implications: The study presents practical implications for concerned authorities to work on dismantling the negative perceptions about female education. The results suggest working closely with several institutions to raise awareness and enlighten parents and family members on the prospects of EIMWT, especially to the female gender.

Originality/value: The study concludes that EIMWT is a way of investing in the education of females in view of breaking cycles of poverty and social vices that the females might be lured into.
\end{abstract}

\section{INTRODUCTION}

The National Academy of Sciences (2017) emphasizes that educating the female gender is a universally accepted strategy for improving lives and advancing development. It went further to assert that the female gender's schooling is associated with many demographic outcomes, 
including later age at marriage or union formation, lower fertility, and better child health. Therefore, it is pertinent to say that the outcome of the female gender enrolment is not just beneficial to the economy of a nation, but also the wellbeing of the person. This is because the females who receive education are less likely to marry at an early age and have fewer children. In addition, these females will be more likely to survive and be better nourished and educated. Educated women are more productive at home and better paid in the workplace, and better able to participate in social, economic, and political decision-making. One aspect of education requiring female participation in Nigeria is Technical Vocational Education and Training (TVET).

The United Nations Educational, Scientific and Cultural Organization [UNESCO] (2016) recommendation concerning TVET recognizes that it contributes towards the promotion of understanding and respect for human rights, inclusion and equity, gender equality and cultural diversity, and to the fostering of a desire and capacity for lifelong learning and learning to live together, all of which are essential to social and economic participation and the realization of lasting peace, responsible citizenship, and sustainable development. UNESCO also supports innovative means to widen access and participation in TVET for vulnerable and disadvantaged groups. One of such disadvantaged groups is the female gender.

The participation of females in TVET (especially technical education programs) in Nigerian institutions is generally low and very poor when compared to enrolment in general education programs (Adelakun, Oviawe, and Garba, 2015; Aina, 2006). Okolocha (2006) noted that since the introduction of TVET into the Nigerian educational system, enrolment in TVET programs in Nigeria has remained low. This poor enrolment is further accentuated in female enrolment in TVET (Ezeliora \& Ezeokana, 2010). This is supported by Agwi and Puyate (2017) whose study revealed that the poor enrolment into TVET programs in Nigeria is more disturbing on female gender's participation. This low enrolment of females in TVET programs has been attributed to several factors. According to Wubon (2013), education has not necessarily been a priority for the female gender because of socio-cultural beliefs and perverted mindsets. It is believed that the place of the girl-child is in her husband's house. The male child is considered to be superior to the female child in many aspects especially education, and that is why in most cases, only the male child has access to education. Similarly, Dokubo and Deebom (2017) hinged the poor enrolment of females on poverty, preference of male children, cultural and religious beliefs. Ayonmike (2014) noted that the government, schools, society, and parents had a role to play in the poor enrolment of the female gender in TVET programs.

Altrajir (2014) pointed out that many parents and community members believe that formal education is not necessary for females to prepare for these expected roles as they can be learned from their mothers and others in the community. As a result, many parents do not enroll their daughters in school or withdraw them before completion. This denies these girls an opportunity for formal education in general and participation in technical subjects in particular. This is corroborated by Hart (2008) who pointed out that many parents and community members also have the attitude that educating females is a waste of time and money because they will eventually be married off and their education would therefore only benefit their husbands and the families they marry into. Money spent on the girl's education would thus be considered lost to the girl's family. There is also the expectation that males will become the "breadwinners" of 
their future families, so many parents and community members feel that males should for this reason be provided with every advantage to help them fulfill this role, this includes educating them as far as possible. Females, on the other hand, are expected to have husbands who will provide for them and education is therefore not essential for them. Peterson and Runyan (2009) added that parents are also reported to discourage their sons from marrying women who were technical graduates as they felt that they would not respect especially those husbands who were non-technical.

The objective of TVET is to prepare and train students to acquire the requisite trade skills that would enable them to secure employment, become self-employed, and be able to employ others or pursue further education in tertiary institutions. Women can also benefit from this; however, students' enrolment records of the three Government Technical Colleges spread across the three educational zones of Adamawa State shows that there is a decline in the enrolment of female students into Electrical Installation and Maintenance Works Trade (Adamawa State PostPrimary Board, 2019). In the 2016-2017 session, out of 70 students that were enrolled, 88.57\% (62 students) were males and $11.43 \%$ (8 students) were females. In the 2017-2018 session, there was an increase in enrolment as 146 students were enrolled; sadly, 94.52\% (138 students) were males, leaving just 5.48\% (8 students) as females. A decrease in enrolment was observed in the 2018/2019 session as 129 students were enrolled; sadly, only 4.65\% (6 students) were females and $95.35 \%$ (123 students) were males. The enrolment records, therefore, reveal that female students' enrolment into Electrical Installation and Maintenance Works Trade in the technical colleges in Adamawa State is low and discouraging. There is, therefore, a need to ascertain the family-related determinants of low female enrolment while also establishing the implications of this trend. Additionally, if this trend in female students' enrolment is not addressed urgently, the Electrical Installation and Maintenance Works Trade of the technical colleges in Adamawa State might end up having no female students enrolled in the program in the near future, thus leaving the Adamawa community with the dearth of female technicians in electrical installations and maintenance. It is against this background that this study was carried out.

\section{Research Hypotheses}

The following null hypotheses $\left(\mathrm{H}_{0}\right)$ were formulated and tested at a 0.05 level of significance.

$\mathrm{H}_{\mathrm{O} 1}$ : There is no significant difference in the mean responses of parents and teachers on perceived family-related determinants of the low enrolment of female students in Electrical Installation and Maintenance Works in Government Science Technical Colleges in Adamawa State.

$\mathrm{H}_{\mathrm{O} 2}$ : There is no significant difference in the mean responses of parents and teachers on perceived family-related implications of the low enrolment of female students in Electrical Installation and Maintenance Works Trade in Government Technical Colleges in Adamawa State. 


\section{METHODOLOGY AND PROCEDURES}

\section{Research Design}

The study adopted a descriptive survey research design. The researchers selected a sample of respondents and administered questionnaires to them.

\section{Sampling}

The population for the study consisted of 142 respondents (13 teachers and 129 parents of NTCII students in EIMWT). There was no sampling because of the small and manageable population.

\section{Data Collection/Data Analysis}

The study involved the use of a structured questionnaire to collect data to assist in the findings of the study. The instrument used for collecting data for this study was a structured questionnaire developed by the researcher for teachers and parents, titled Perceived Determinants and Economic Implications of Low Female Enrolment Questionnaire (PDEILFEQ). The questionnaire was divided into two sub-sections based on the two research questions that guided the study. The responses on the questionnaire were structured on 5-point Likert scale of Strongly Agree $(\mathrm{SA})=5$, Agree $(\mathrm{A})=4$, Undecided $(\mathrm{U})=3$, Disagree $(\mathrm{D})=2$ and Strongly Disagree $(\mathrm{SD})=1$. The questionnaire was validated by three experts from the Department of Electrical Technology Education, Modibbo Adama University, Yola, Adamawa State. Before embarking on fieldwork, the structured questionnaire designed by the researcher to collect data was trial tested in Government Technical College Jalingo, Taraba State, which is not part of the study area to determine the reliability of the instrument. The data from this trial testing were analyzed using Cronbach's alpha. The Cronbach alpha was found to be 0.87 and the instrument was adjudged highly reliable. The researcher then proceeded to administer the questionnaire to the respondents. Administering of the questionnaire was carried out within five weeks and the researcher had $100 \%$ recovery of the questionnaires issued out. A total of 142 copies of the structured questionnaire were filled and returned. The data collected were presented in tables. Mean and Standard Deviation were used to answer the research questions while the null hypotheses were tested using a t-test. In answering the Research Questions, an item with a mean of 3.50 and above was considered as Agreed (A) while an item with a mean less than 3.50 (3.49 and below) was considered as Disagreed (D). In interpreting the result of the t-test analysis as contained in the SPSS output, where the $p$-value was greater than .05 ( $p>$ .05 ), the null hypothesis was accepted and where the $p$-value was less than or equal to .05 ( $p \leq$ $.05)$, the null hypothesis was rejected. The data collected for this study were analyzed using Statistical Package for Social Sciences (SPSS) version 20.0

\section{RESULTS AND DISCUSSION}

Perceived family-related determinants of the low enrolment of female students in Electrical Installation and Maintenance Works in Government Science Technical Colleges in Adamawa State 
Table 1: $\quad$ Mean ratings and standard deviations of teachers and parents responses on the perceived family-related determinants of the low enrolment of female students

\begin{tabular}{|c|c|c|c|c|c|c|c|c|}
\hline \multirow[t]{2}{*}{$\begin{array}{l}\mathrm{S} / \\
\mathrm{N}\end{array}$} & \multirow[t]{2}{*}{ Items } & \multicolumn{6}{|c|}{$\begin{array}{c}\text { Respondents } \\
\mathrm{n}_{\mathrm{T}}=13, \mathrm{n}_{\mathrm{P}}=129, \mathrm{n}_{\mathrm{G}}=142\end{array}$} & \multirow[t]{2}{*}{ Remarks } \\
\hline & & $\bar{x}_{T}$ & $\sigma_{T}$ & $\bar{x}_{P}$ & $\sigma_{P}$ & $\bar{x}_{G}$ & $\sigma_{G}$ & \\
\hline 1. & $\begin{array}{l}\text { Parents and family members' } \\
\text { poor perception of female gender } \\
\text { education }\end{array}$ & 3.84 & 0.89 & 3.74 & 1.19 & 3.75 & 1.16 & Agreed \\
\hline 2. & Lack of family members support & 3.69 & 0.94 & 4.34 & 0.76 & 4.28 & 0.80 & Agreed \\
\hline 3. & $\begin{array}{l}\text { Family beliefs that Electrical } \\
\text { Installation and Maintenance } \\
\text { Works Trade requires physical } \\
\text { strength }\end{array}$ & 3.69 & 0.94 & 3.85 & 1.42 & 3.83 & 1.38 & Agreed \\
\hline 4. & $\begin{array}{l}\text { Family belief that the chores at } \\
\text { home are difficult to combine } \\
\text { with study of Electrical } \\
\text { Installation and Maintenance } \\
\text { Work Trade }\end{array}$ & 3.46 & 1.12 & 3.30 & 1.05 & 3.31 & 1.05 & Disagreed \\
\hline 5. & $\begin{array}{l}\text { Unwillingness of parents to } \\
\text { allow girls to travel long } \\
\text { distances to study Electrical } \\
\text { Installation and Maintenance } \\
\text { Works Trade }\end{array}$ & 3.84 & 0.68 & 3.49 & 1.34 & 3.52 & 1.29 & Agreed \\
\hline 6. & $\begin{array}{l}\text { Family perception about female } \\
\text { child working with electricity }\end{array}$ & 3.92 & 0.49 & 3.89 & 1.15 & 3.89 & 1.10 & Agreed \\
\hline 7. & $\begin{array}{l}\text { Families prioritizing early } \\
\text { marriage over education }\end{array}$ & 4.00 & 0.70 & 3.28 & 1.48 & 3.35 & 1.44 & Disagreed \\
\hline 8. & Family restriction due to religion & 3.46 & 1.19 & 3.47 & 1.19 & 3.47 & 1.19 & Disagreed \\
\hline 9. & $\begin{array}{l}\text { Family members' fear of hazards } \\
\text { involved in working with } \\
\text { electricity }\end{array}$ & 4.15 & 0.80 & 3.78 & 1.38 & 3.81 & 1.34 & Agreed \\
\hline 10. & $\begin{array}{l}\text { Illiteracy of mothers/female } \\
\text { guardians }\end{array}$ & 3.84 & 1.14 & 3.07 & 1.58 & 3.14 & 1.56 & Disagreed \\
\hline & Grand Mean & 3.78 & & 3.62 & & 3.63 & & Agreed \\
\hline
\end{tabular}

Results presented in Table 1 above showed that the respondents (teachers and parents) agreed on six out of 10 perceived family-related determinants of the low enrolment of female students in Electrical Installation and Maintenance Works in Government Science Technical Colleges in Adamawa State based on the item mean of means ranging from 3.75 to 4.28 . Specifically, the respondents did not consider the family's belief that the chores at home are difficult to combine with study of Electrical Installation and Maintenance Work Trade, families prioritizing early marriage over education, family restriction due to religion, and illiteracy of mothers/female guardians as perceived family-related determinants of low enrolment of female students. Given a grand mean of 3.63, the respondents agreed on the perceived family-related determinants of low enrolment of female students in Electrical Installation and Maintenance Works in Government Science Technical Colleges in Adamawa State. Furthermore, with standard 
deviation ranging from 0.80 to 1.56 , the results indicate that there is little dispersion in the opinions of the respondents.

Perceived family-related implications of the low enrolment of female students in Electrical Installation and Maintenance Works Trade in Government Science Technical Colleges in Adamawa State

Table 2: $\quad$ Mean ratings and standard deviations of teachers and parents responses on the perceived family-related implications of low enrolment of female students

\begin{tabular}{|c|c|c|c|c|c|c|c|c|}
\hline S/ & Items & & & Resp & ents & & & Remarks \\
\hline $\mathrm{N}$ & & $\bar{x}_{T}$ & $\sigma_{T}$ & $\bar{x}_{P}$ & $\sigma_{P}$ & $\bar{x}_{G}$ & $\sigma_{G}$ & \\
\hline 11. & $\begin{array}{l}\text { Decline in family living } \\
\text { standards in Adamawa State due } \\
\text { to lack of self-reliance of female } \\
\text { folks in Adamawa State }\end{array}$ & 3.46 & 0.87 & 3.45 & 1.39 & 3.45 & 1.35 & Disagreed \\
\hline 12. & $\begin{array}{l}\text { Increased level of dependency of } \\
\text { the female gender on the males } \\
\text { in Adamawa State }\end{array}$ & 3.23 & 1.09 & 3.77 & 1.28 & 3.72 & 1.27 & Agreed \\
\hline 13. & $\begin{array}{l}\text { Inability for the early married } \\
\text { females in Adamawa State to } \\
\text { support their families financially }\end{array}$ & 2.92 & 1.11 & 3.62 & 1.27 & 3.56 & 1.27 & Agreed \\
\hline 14. & $\begin{array}{l}\text { Promotes inequality in the } \\
\text { family }\end{array}$ & 3.84 & 0.98 & 3.31 & 1.40 & 3.35 & 1.37 & Disagreed \\
\hline 15. & $\begin{array}{l}\text { Poor earning power among the } \\
\text { female gender in Adamawa State }\end{array}$ & 3.38 & 1.19 & 3.68 & 1.19 & 3.66 & 1.19 & Agreed \\
\hline 16. & $\begin{array}{l}\text { It has contributed to the } \\
\text { unproductivity of the female } \\
\text { gender in some homes of } \\
\text { Adamawa State }\end{array}$ & 3.46 & 1.12 & 3.37 & 1.19 & 3.38 & 1.18 & Disagreed \\
\hline 17. & $\begin{array}{l}\text { It has contributed to increased } \\
\text { poverty in some homes of } \\
\text { Adamawa State }\end{array}$ & 3.15 & 1.06 & 3.25 & 1.45 & 3.24 & 1.42 & Disagreed \\
\hline 18. & $\begin{array}{l}\text { Diminished quality of life in } \\
\text { households of Adamawa State }\end{array}$ & 2.76 & 1.09 & 3.15 & 1.14 & 3.11 & 1.14 & Disagreed \\
\hline 19. & $\begin{array}{l}\text { Low contribution from the } \\
\text { female gender to family income } \\
\text { in households of Adamawa State }\end{array}$ & 3.38 & 1.26 & 3.99 & 0.87 & 3.93 & 0.93 & Agreed \\
\hline 20. & Low contribution from the & 3.53 & 1.19 & 3.35 & 1.37 & 3.37 & 1.35 & Disagreed \\
\hline
\end{tabular}
of Adamawa State

Grand Mean

$3.31 \quad 3.49$

3.47

Disagreed

$\bar{x}_{T}=$ Mean responses of Teachers, $\bar{x}_{p}=$ Mean responses of Parents, $\sigma_{T}=$ Standard Deviation of Teachers, $\sigma_{P}=$ Standard Deviation of Parents, $\bar{x}_{G}=$ Grand mean, $\sigma_{G}=$ Grand Standard Deviation.

Data presented in Table 2 above showed that the respondents (teachers and parents) agreed on four out of 10 perceived family-related implications of the low enrolment of female students in Electrical Installation and Maintenance Works Trade in Government Technical Colleges in Adamawa State based on the item mean of means ranging from 3.56 to 3.93. Specifically, the respondents did not consider the decline in family living standards in Adamawa State due to lack of self-reliance of female folks in Adamawa State, promotion of inequality in the family, 
contribution to the unproductivity of the female gender in some homes of Adamawa State, contribution to increased poverty in some homes of Adamawa State, diminished quality of life in households of Adamawa State, and low contribution from the female gender to the productivity of Adamawa State as perceived family-related implications of the low enrolment of female students. Given a grand mean of 3.47, the respondents disagreed on the perceived family-related implications of the low enrolment of female students in Electrical Installation and Maintenance Works Trade in Government Technical Colleges in Adamawa State. Furthermore, with a standard deviation ranging from 0.93 to 1.42 , the results indicate that the opinions of the respondents are clustered around the mean response.

$\mathrm{H}_{01}$ : There is no significant difference in the mean responses of parents and teachers on perceived family-related determinants of the low enrolment of female students in Electrical Installation and Maintenance Works in Government Science Technical Colleges in Adamawa State.

Table 3: t-Test analysis of responses on the perceived family-related determinants of the low enrolment of female students

\begin{tabular}{lcccccccc}
\hline & $\bar{x}$ & $\sigma$ & $\mathrm{n}$ & $\mathrm{df}$ & $\alpha$ & $\mathrm{t}_{\mathrm{cal}}$ & $p$ & Decision \\
\hline Teachers & 3.79 & 0.44 & 13 & & & & & \\
& & & & 140 & 0.05 & 0.96 & 0.33 & Accepted \\
Parents & 3.62 & 0.60 & 129 & & & & & \\
\hline
\end{tabular}

KEY: $\quad \bar{x}=$ Mean, $\sigma=$ Standard Deviation, $\mathrm{n}=$ Number of Respondents, $\mathrm{df}=$ Degree of Freedom, $\alpha=$ level of significance, $\mathrm{t}_{\mathrm{cal}}=$ Calculated $\mathrm{t}$-value, $p=$ Significance (2-tailed)

The result in Table 3 reveals a $t_{\text {cal }}$ of 0.96 with a $p$-value of 0.33 . Since the $p$-value is greater than the alpha level of the test ( $p>.05)$, the null hypothesis is accepted. This means that there is no significant difference in the mean responses of parents and teachers on perceived familyrelated determinants of the low enrolment of female students in Electrical Installation and Maintenance Works in Government Science Technical Colleges in Adamawa State.

$\mathrm{H}_{02}$ : There is no significant difference in the mean responses of parents and teachers on perceived family-related implications of the low enrolment of female students in Electrical Installation and Maintenance Works Trade in Government Technical Colleges in Adamawa State.

Table 4: t-Test analysis of responses on the perceived family-related implications of the low enrolment of female students

\begin{tabular}{|c|c|c|c|c|c|c|c|c|}
\hline & $\bar{x}$ & $\sigma$ & $\mathrm{n}$ & df & $\alpha$ & $\mathrm{t}_{\mathrm{cal}}$ & $p$ & Decision \\
\hline Teachers & 3.31 & 0.67 & 13 & & & & & \\
\hline & & & & 140 & 0.05 & 1.00 & 0.31 & Accepted \\
\hline Parents & 3.49 & 0.62 & 129 & & & & & \\
\hline
\end{tabular}


The result in Table 4 reveals a $\mathrm{t}_{\mathrm{cal}}$ of 1.00 with a $p$-value of 0.31 . Since the $p$-value is greater than the alpha level of the test ( $p>.05)$, the null hypothesis is accepted. This means that there is no significant difference in the mean responses of parents and teachers on perceived familyrelated implications of low enrolment of female students in Electrical Installation and Maintenance Works Trade in Government Technical Colleges in Adamawa State.

\section{Discussion}

Findings with respect to research question one shows that the respondents (teachers and parents) agreed on six out 10 perceived family-related determinants of low enrolment of female students in Electrical Installation and Maintenance Works in Government Science Technical Colleges in Adamawa State which are: Parents and family members' poor perception of female gender education, Lack of family members support, Family beliefs that Electrical Installation and Maintenance Works Trade requires physical strength, Unwillingness of parents to allow girls to travel long distances to study Electrical Installation and Maintenance Works Trade, Family perception about a female child working with electricity, and Family members' fear of hazards involved in working with electricity. This finding is consistent with studies by Ayonmike (2014), Adelakun, Oviawe, and Barfa (2015), Dokubo and Deebom (2017), and Altrajir (cited in Khaguya, 2014), which revealed that poor parental perceptions about the benefits of female education and an unwillingness to allow girls to travel long distances constitute perceived family-related determinants of the low enrolment of female students. Furthermore, the respondents did not consider the family's belief that the chores at home are difficult to combine with study of Electrical Installation and Maintenance Work Trade, families prioritizing early marriage over education, family restriction due to religion, and illiteracy of mothers/female guardians as perceived family-related determinants of the low enrolment of female students. This finding is distinct from the study by Ayonmike (2014) which revealed religious and sociocultural traditions as a factor affecting female enrolment. The corresponding hypothesis test shows that the parents and teachers shared similar opinions on the perceived family-related determinants of the low enrolment of female students in Electrical Installation and Maintenance Works in Government Science Technical Colleges in Adamawa State.

The findings with respect to research question two show that the respondents (teachers and parents) agreed on four out of 10 perceived family-related implications of the low enrolment of female students in Electrical Installation and Maintenance Works Trade in Government Science Technical Colleges in Adamawa State which is increased level of dependency of the female gender on the males in Adamawa State, Inability for the early married females in Adamawa State to support their families financially, Poor earning power among the female gender in Adamawa State, and Low contribution from the female gender to family income in households of Adamawa State. Furthermore, the respondents did not consider the decline in family living standards in Adamawa State due to lack of self-reliance of female folks in Adamawa State, promotion of inequality in the family, contribution to the unproductivity of the female gender in some homes of Adamawa State, contribution to increased poverty in some homes of Adamawa State, diminished quality of life in households of Adamawa State, and low contribution from the female gender to the productivity of Adamawa State as perceived family-related implications of the low enrolment of female students. This finding is distinct from the study by Ngelu, Omwenga, Mungatu, and Iravo (2018) which revealed that female enrolment in education is 
more likely to improve the quality of life for the household as compared to not enrolling. The corresponding hypothesis test shows that the parents and teachers shared similar opinions on the perceived family-related implications of the low enrolment of female students in Electrical Installation and Maintenance Works Trade in Government Science Technical Colleges in Adamawa State.

\section{CONCLUSION AND SUGGESTION}

Based on the findings of the study, it can be concluded that lack of family members' support and family perception about the female child working electricity is the major perceived familyrelated determinants of low female enrolment in Electrical Installation and Maintenance Works in Government Science Technical Colleges in Adamawa State. It can also be concluded that low contribution from the female gender to family income in households and the increased level of dependency of the female gender on the males in Adamawa State are the major perceived family-related implications of low female enrolment in Electrical Installation and Maintenance Works in Government Science Technical Colleges in Adamawa State. Therefore, mechanisms should be put in place to adapt and improve female enrolment into EIMWT as a way of investing in the education of females in view of breaking cycles of poverty and social vices that the females might be lured into, thereby bringing about economic growth.

In view of the findings of the study, The Adamawa state government in collaboration with corporate bodies should embark on an awareness campaign to enlighten parents and family members of the prospects of EIMWT especially to the female gender, as an avenue of disabusing their poor perception of female gender education and securing the support of the family members. EIMWT teachers in Adamawa State in collaboration with corporate bodies should organize empowerment seminars to enlighten the female gender on how their enrolment into the trade will increase their contribution to family income in households and reduce their level of dependency on the males.

\section{CONFLICT OF INTEREST}

There are no conflicts of interest with this paper.

\section{FUNDING}

I did not receive any funding to complete this research.

\section{REFERENCES}

Adamawa State Post-Primary Board (2019). Demographic Information on Electrical Installation and Maintenance Works Trade in Technical Colleges of Adamawa State.

Adelakun, O. A., Oviawe, J. I., \& Garba, G. I. (2015). Strategies for Enhancing Female Participation in Technical, Vocational Educcation and Training (TVET) in Nigeria. Advances in Social Sciences Research Journal, 2(4), 11-20. https://doi.org/10.14738/assrj.24.1041 
Agwi, V. I. A. \& Puyate, S. T. (2017). Strategies for improving female students enrolment in technical vocational education and training (TVET) programmes in Rivers and Bayelsa States. Journal of Education in Development Areas, 25(1), 65-80.

Aina, O. (2006). Education Trust Fund Sanitization Workshop: Technical and Vocational Education (TVE) in Nigeria: the way Forward. Ilorin: Apex Press Nigeria Ltd.

Ayonmike, C. S. (2014). Factors Affecting Female Participation in Technical Education Programme: A Study of Delta State University, Abraka. Journal of Education and Human Development, 3(3): 227-240. https://doi.org/10.15640/jehd.v3n3a18

Dokubo, N. I. \& Deebom, M. T. (2017). Gender disparity towards students enrollment in technical education in rivers state: causes, effects and strategies. International Journal of Research - Granthaalayah, 5(10), 1-10. https://doi.org/10.5281/zenodo.1039567

Ezeliora, B. \& Ezeokana, J. O. (2010). Inhibiting influences of some traditional practices in the home on girl-child's scientific development. International Journal of FAWE Nigeria, 2(1), 31-42.

Hart, J. (2008). Mobilization among women academics: the interplay between feminism and professionalism. NWSA Journal, 20(1), 184-208. https://doi.org/10.1353/nwsa.0.0003

Khaguya, L. (2014). Factors influencing female students enrolment in technical courses: A case of Matili Technical Training Institute, Kenya. http://erepository.uonbi.ac.ke/bitstream/handle/11295/73939/Khaguya_Factors\%20influe ncing\%20female\%20students\%20enrollment\%20in\%20technical\%20courses.pdf;sequen ce $=3$ (Retrieved 20th February 2021)

Ngelu, J. M., Omwenga, J., Mungatu, J., \& Iravo, M. (2018). Effect of gender empowerment programmes on improving quality of life in Kenya: Evidence from Machakos County. Microeconomics and Macroeconomics, 6(1), 9-19. https://doi.org/10.15640/jeds.v5n3a6

Okolocha, C. C. (2006). Vocational technical education in Nigeria: Challenges and the wayforward. Unizik Orient Journal of Education, 2(1), 180-119.

Peterson, V. S. \& Runyan, A. S. (2009). Global Gender Issues, 2nd edn. Colorado: Westview. Shakeshaft C 2009. Women in Educational Management. Newbury Park: Sage

Statistical Package for Social Sciences (2011). IBM Statistical Package for Social Sciences: User's Guide. Version 20.0 for windows. IBM Corp., Armonk, NY.

The National Academy of Sciences (2017). The demographic effects of girls education in developing countries: A workshop. https://www.nationalacademies.org/our-work/thedemographic-effects-of-girls-education-in-developing-countries-a-workshop (Retrieved 20th February 2021)

United Nations Educational, Scientific and Cultural Organization (2016). Recommendation concerning Technical and Vocational Education and Training (TVET). https://unesdoc.unesco.org/ark:/48223/pf0000245068.page=5 (Retrieved on 6th August 2019).

Wubon, A. (2013). Girl-Child Education: Important for National Development. Daily Independent, Nigeria Newspaper (Retrieved $20^{\text {th }}$ May 2014) 